\title{
Effectivity of Mastery Content Services in Counseling to Improved Creativity for Early Childhood Parents at BKB PAUD Al-Fath
}

\author{
Solihatun \\ Department of Guidance and Counseling \\ Universitas Indraprasta PGRI \\ Jakarta, Indonesia \\ solihatun@unindra.ac.id \\ Sisca Folastri \\ Department of Guidance and Counseling \\ Universitas Indraprasta PGRI \\ Jakarta, Indonesia \\ sisca.folastri@unindra.ac.id
}

\author{
Itsar Bolo Rangka \\ Department of Guidance and Counseling \\ Universitas Indraprasta PGRI \\ Jakarta, Indonesia \\ itsarbolo.rangka@unindra.ac.id
}

\author{
Evi Fitriyanti \\ Department of Guidance and Counseling \\ Universitas Indraprasta PGRI \\ Jakarta, Indonesia \\ evi.fitriyanti@unindra.ac.id
}

\author{
Burju Ruth \\ Department of Guidance and Counseling \\ Universitas Indraprasta PGRI \\ Jakarta, Indonesia \\ burju.ruth@unindra.ac.id
}

\begin{abstract}
Parent's creativity very necessary to support earlychildhood development. This study aimed to determine the level creativity of early-childhood parents through mastery content services in counseling. Subject in this study involved 13 EarlyChildhood Parents at BKB PAUD Al-Fath. Data analysis used a quantitative approach with experimental pre-test and post-test control group one design. The result showed mastery content services in counseling is effective at improving creativity of earlychildhood parents at BKB PAUD Al-Fath.
\end{abstract}

Keywords-mastery content services; counseling, parents creativity

\section{INTRODUCTION}

Childhood is a period considered as a learning phase to obtain abilities [1]. If a child is not presented with the chance to exercise, and certain skills, when they are capable of doing so, they will not only lack the basic skills that their peers have obtained and practiced, but they will also lack the motivation to seek and learn new skills should they be given with the chance [2].

There are three reasons to why children learn a certain skillset, for instance: (1) the child is learning through repetitive pattern and because of that, they willingly repeat a sequence of activity, until they become fluent. (2) the child is brave and/or curious enough, so they are not obstructed by fear that they might experience pain or to be mocked by their peers, (3) young children are more perceptive towards new knowledge because they are still very flexible. So they knowledge they are about to obtain will not infare with the knowledge they have previously mastered[3].

Parents are adult individuals responsible for the education of their kids[4], thus, the success of their kids are highly dependent to the parenting. It is imperative for the parents to possess a sense of creativity to develop the abilities of their children, educating them on a day to day basis. Creativity is a condition, which is very specific and almost impossible to be summarized[5], nor is it to be simply understood through a single formula[6], [7].

That being said, it is possible to conclude that humans are born with creativity[7]. But it is only to obtain its full capability if it is correctly trained and developed[8]. Nowadays, it is considered a general and widely-known practice, for the parents to develop their own creative abilities so that they can do so to their children. As it is found at $\mathrm{Al}$ Fath, Ciganjur, East Jakarta. Through the mastery content service, it is expected that the parents of Paud Al Fath's pupils will possess knowledge and competence on content-mastering to later teach their children the same, in order to develop their children's capability, and creativity[9], [10]. The mastery content services is included as a service of guidance and counseling[11] which helps individuals on mastering a certain, specific contents[12]. Especially in the competence or habit on doing, exercising or the likes -- of activities that are useful on their lives. Be it in an academical, familial, or societal scope. Also, it is hoped of them to develop an honorable traits which corresponds to their interests, and potentials[13]. Their competence and capability they are learning, is a content unit 
which contains facts, concepts, process, laws orders, values, perception, affection, behavior, and actions. Through contentmastering, the individuals are expected to be capable on solving the problems or obstacles they are faced with, integrative, to fulfill their wants and needs.

\section{METHOD}

Methods used in this research is the quantitative methods with experimental design. The Pre-Experiment Design applied is "One-Group Pretest-Posttest Designs". Research is conducted at BKB PAUD AL-FATH Ciganjur Jakarta Selatan. The samples taken for this research are 13 parents of the pupils. Writer applied the techniques of purposive sampling, which is a technique to "select samples that are seen to be fitting to specific characteristic's that has a connection to a population's characteristic, that has been discovered previous to the latest research"[14]. To measure creativity used scale creativity of parents (SKO) is constructed by the researchers. Estimation of SKO scale reliability coefficient reached 0.77 . Activities are held for four days.

\section{RESUlT AND DisCUSSIONS}

The analytical description of the data is done to determine the average condition (mean), mid value (median), the topmost value (mode), variants, highest score, also the lowest score.

TABLE I. PRE-TeSt AND POST-TEST CREATIVITy SCORE

\begin{tabular}{lcc}
\hline & Pre-Test & Post-Test \\
\hline Mean & 155.69 & 187.54 \\
Median & 159.00 & 186.00 \\
Mode & $160^{\mathrm{a}}$ & $164^{\mathrm{a}}$ \\
Std. Deviation & 7.782 & 21.161 \\
Variance & 60.564 & 447.769 \\
Minimum & 141 & 164 \\
Maximum & 165 & 217 \\
Total & 2024 & 2438 \\
\hline
\end{tabular}

From the stated description, it is explained that between the mean and median is not significantly different, with the close margin between 155.69 and 159.00. This shows that the data score on the pre-test creativity in this research is adequately representative. Whereas the score being above the average appears more than the scores below average. Thus, a conclusion can be drawn that there are more respondents with higher level of creativity, than respondents with lower value of creativity. Based on the refined data, the values under average only consists of 5 respondents $(38.41 \%)$, while the remaining 8 scored above average. From the distribution table, histogram, and frequency polygon, it is possible to draw a conclusion that the data of creativity pre-test in this research has a relatively normal spread and distribution.

The margin between the value of the mean, and the value of the median is not significant. It is between 187.54 and 186.00. This explains that the creativity post-test on this research is sufficiently representative. Meanwhile, the scores valuing above the average are more than the scores valuing below. This explains that there are more respondents possessing an above average creativity, than the below average respondents.

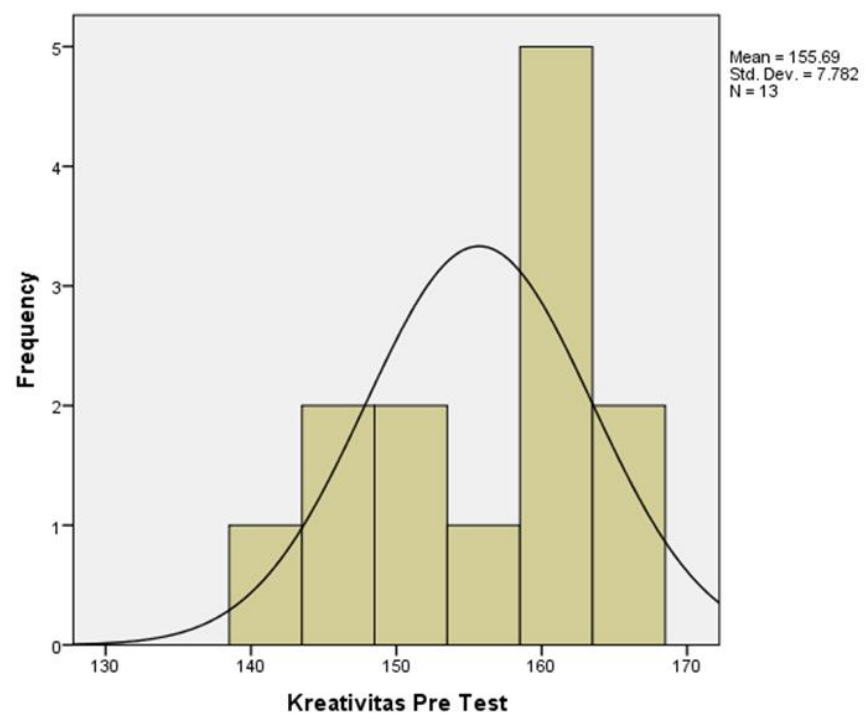

Fig. 1. Pre-test Histogram based on creativity scores

Based on the refined data, there are 7 respondents scoring below average $(53.84 \%)$ and 6 respondents scoring above average. From the distribution table, histogram, and frequency polygon, it is possible to draw a conclusion that the data of creativity pre-test in this research has a relatively normal spread and distribution.

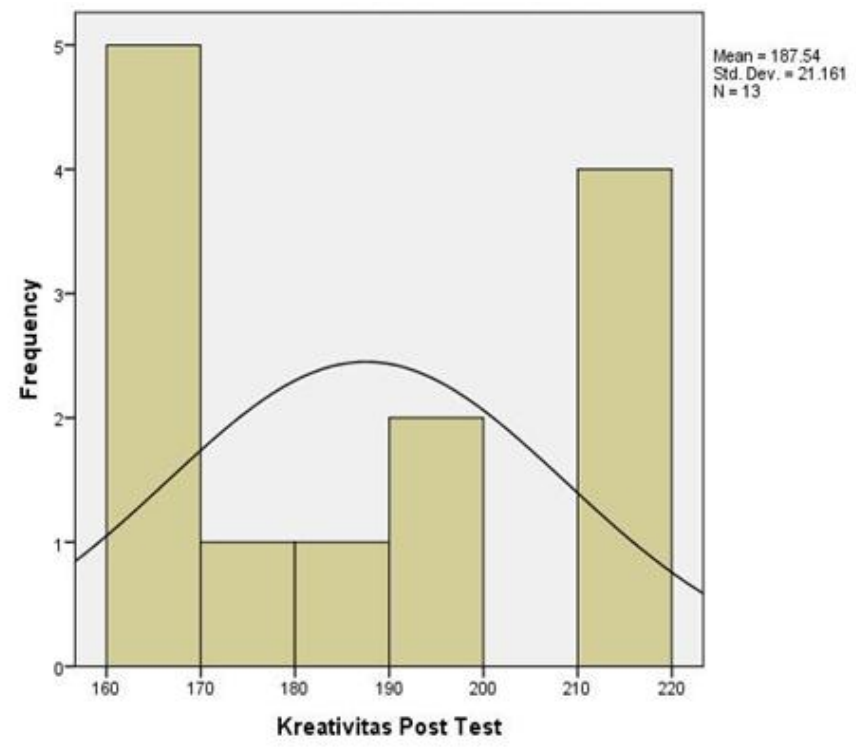

Fig. 2. Post-test Histogram based on creativity scores

The examination of the hypothesis on this research is whether there is an enhancement between before and after the test (pre and post-test). As explained before the examination is done based on the refined data as stated the margin of the average creativity before, and after the test is 31.84 . Examinations with $t$-test, gives the value of $t=5.31$ with the independent degree of $=n-1=13-1=12$. The SPSS output gives 
the-value to be tested (2-tailed) $=0,000$. P-value for 2-tailed test is lesser than $\alpha=0,05$, so that the evidence strongly objects. It is based on those evidences, that the test is effective to prove the significant margin and enhancement between the value of creativity, before and after the test.

Creativity program activities through content mastery service is held for four days. The first day, giving the material with the theme of the importance of improving the creative ideas of parents to develop the skills of children through the material "Creativity of children in shaping the character of early age". Mastery content service is expected parents are able to develop the creativity of children with a precise and positive to form a smart character in children in acting and behaving because children learn from his life. Therefore, there is only one science that educates educational science that is based on love and love of children and able to develop creative ideas of children.

The second day of the mastery content service continued with the theme of making the game playdough environmentally friendly with a duration of activity for two hours. The ingredients are wheat flour, cooking oil, salt, food coloring, and water. All the ingredients are mixed except for food coloring. After the dough is formed, parents and children are asked to take a little dough and add food coloring. The dough can use one or two colors, in this activity the child will explore the power of creativity in combining colors and recognize the color. This activity to making a game that will be a good relationship between parents and children through interactive and educational activities, there is also mixing activities of materials and colors in making playdough game that contains the meaning of the mixing of materials and colors accordingly then the results will be beautiful, caught the attention of children to recognize games that are environmentally friendly and educative. This game is the same as the life between parent and child if the relationship is affixed with love and togetherness between parent and child then the relationship will cultivate mutual love, needs and mutual respect.

Third day continued with the theme inflated balloon without inflatable is a game where there is a measure of composition in making balloons balloon the more its composition in accordance with the expected size the better the balloon bubble, then the relationship with the composition of the material in inflating the balloon has something to do with the meaning of making the game i.e the more intensity of closeness between parents and children, the better the relationship between parents and children. Similarly, vice versa when the intensity of closeness between parents with little children, then the relationship between parents with children less good. Ingredients: balloons, plastic bottles used, vinegar and baking soda with a duration of one hour. The way is; a plastic bottle filled with vinegar, a balloon filled with baking soda and a balloon paired to a plastic bottle and slowly dropping the baking soda into the vinegar so slowly ballooning.

The last day closes with the theme of making hours from used materials and environmentally friendly. The ingredients include carton, bottle drink, bottle cap, glue gunshot. This game has the meaning that in our environment there are environmentally friendly materials that can be utilized to develop children's creative ideas, learning tools and have an educative value.

\section{CONCLUSIONS}

A conclusion is drawn that the pre-test creativity score obtained from the 13 respondents as samples has the mean of 155.69 with the standard deviation of 7.782. Median of 159.00; mode of 160; minimum score of 141, and the maximum score of 165 . Thus, the pre-test creativity score can be classified as adequate/good. Whereas the post-test creativity score obtained from the respondents has the mean if 187.54 , with the standard deviation if 21.161 ; median of 186,00 ; mode of 164 ; with the minimum score of 164 and the maximum score of 217 . Thus, the pre-test creativity score can be classified as adequate/good.

With the data obtained, refined and analyzed, the contentmastering service proved to be effective in enhancing the creativity for the students' parents of BKB PAUD Al Fath Ciganjur. As so, it is hopes it will be applicative for the parents, to teach the knowledge on to their kids on their daily lives and activities.

\section{Acknowledgment}

We would like to thank to Institute for Research and Community Services Universitas Indraprasta PGRI for the financial assistant under the Fundamental Research Grant. We express our great appreciation to all of the children and Parents in BKB PAUD Al-Fath Jakarta who participated and their friendly cooperation, and Ms. Nosmalasari for technical help in this manuscript.

\section{References}

[1] S. B. Rimm, Mendidik dan menerapkan disiplin pada anak prasekolah: pola asuh anak masa kini. Gramedia Pustaka Utama, 2003.

[2] S. Rahardjo and E. Zamroni, "Teori dan Praktik Pemahaman Individu Teknik Testing." Badan Penerbit Universitas Muria Kudus, 2017.

[3] E. B. Hurlock, Developmental psychology. Tata McGraw-Hill Education, 2001.

[4] A. M. A. Mubarok, "Studi Pola Pendidikan Orang Tua dalam Pembentukan Kepribadian Anak di Dusun Karangrejo Gempol Pasuruan," al-Murabbi, vol. 2, no. 1, pp. 1-20, 2017.

[5] R. Evans, Berfikir Kreatif. Jakarta: PT. Bumi Aksara., 1991.

[6] C. R. Semiawan, "Belajar dan Pembelajaran dalam Taraf Usia Dini," Jakarta PT Ikrar Mandiri Abadi, 2002.

[7] R. S. Conny, I. M. Putrawan, and T. H. I. Setiawan, "Dimensi Kreatif dalam Filsafat Ilmu," Bandung PT Remaja Rosdakarya, 2004.

[8] I. B. P. Arnyana, "Pengembangan peta pikiran untuk peningkatan kecakapan berpikir kreatif siswa," J. Pendidik. dan Pengajaran, no. 3, pp. 87-99, 2007.

[9] W. Gulo, Strategi Belajar Mengajar (Cover Baru). Grasindo, 2008.

[10] W. Sri Hastuti and W. S. Winkel, "Bimbingan dan Konseling di Institusi Pendidikan.” Yogyakarta: Media Abadi, 2004.

[11] M. Surya, Psikologi Konseling. Bandung: CV Maestro, 2009.

[12] Prayitno, Jenis Layanan dan Kegiatan Pendukung Konseling. Padang: Jurusan Bimbingan dan Konseling FIP-UNP, 2012.

[13] M. E. Wibowo, "Konseling Kelompok Perkembangan," Semarang UNNES Pers, 2005. 
[14] Sugiono, "Metode penelitian pendidikan (pendekatan kuantitatif, kualitatif dan R\&D)." Bandung: Alfabeta, 2008. 